\title{
A FORÇA COGENTE DAS NORMAS PREVIDENCIÁRIAS NAS CONVENÇÕES E NOS ACORDOS COLETIVOS DE TRABALHO
}

\author{
Suzani Andrade Ferraro
}

Doutora em Direito pela PUC-SP, Pontifícia Universidade Católica de São Paulo e Professora de Direito do Trabalho, Processo do Trabalho e Direito Previdenciário da UFRRJ- Universidade Federal Rural do Rio de Janeiro.

\section{Resumo}

Os direitos previdenciários oriundos das convençóes e dos acordos coletivos de trabalho são direitos fundamentais sociais de destacada relevância social na medida em que as categorias profissionais que celebram as convençôes e os acordos coletivos podem lutar para que os direitos conquistados sejam incorporados definitivamente ao patrimônio individual dos trabalhadores. Neste sentido, foram eleitos os princípios da ultratividade, da norma mais favorável, da dignidade humana e da vedação do retrocesso social. Este trabalho pretende demonstrar a força cogente das normas previdenciárias nas convençôes e nos acordos coletivos de trabalho, pois, uma vez estabelecidas, as condiçóes mais favoráveis nas Convençôes ou Acordos Coletivos, estas devem incorporar-se ao patrimônio jurídico do trabalhador e náo podem mais ser suprimidas, pois a não incorporação dessas normas mais benéficas ao patrimônio jurídico do trabalhador vai significar um retrocesso social que confere aos direitos fundamentais, em especial, aos sociais, estabilidade nas conquistas dispostas na Carta Magna.

\section{Palavras-chave}

Fontes do direito previdenciário; Negociaçáo coletiva do trabalho; Sistema jurídico de previdência social no Brasil; Convençôes coletivas de trabalho; Acordos coletivos de trabalho; Ultratividade; Norma mais favorável; Proibição do retrocesso social.

\section{Resumen}

Derechos de pensión que viene de los convenios y acuerdos colectivos de trabajo son derechos sociales fundamentales resaltados relevancia social en que las categorías profesionales que celebran las convenciones y los convenios colectivos pueden luchar por los derechos adquiridos se incorporan de forma permanente en los patriminio individuales de los trabajadores. En este sentido, los principios de ultratividade fueron elegidos, bien como 
en la norma más favorable a la dignidad humana y el prohibición de la regresión social. Este trabajo tiene como objetivo demostrar la fuerza de las normas imperativas de seguridad social en los convenios y acuerdos colectivos de trabajo, ya que, una vez establecidas, las condiciones más favorables en los acuerdos o convenios de negociación colectiva, que se incorporarán al patrimonio jurídico del trabajador y ya no pueden ser suprimido, por no incorporar estas normas más beneficiosas para el patrimonio jurídico del trabajador supondrá una regresión social que otorga derechos fundamentales, en particular, al desarrollo social, la estabilidad en los logros dispuestas en la Carta Magna.

\section{Palabra clave}

Fuentes de la ley de seguridad social; La mano de obra la negociación colectiva; Sistema de seguridad social legal en Brasil; Convenios colectivos de trabajo; Convenios colectivos; Ultratividade disposición más favorable; La prohibición de regresión social.

\section{Introdução}

Os direitos previdenciários oriundos das convençóes e dos acordos coletivos de trabalho são direitos fundamentais sociais de destacada relevância social na medida em que as categorias profissionais que celebram as convençóes e os acordos coletivos podem lutar para que os direitos conquistados sejam incorporados definitivamente ao patrimônio coletivo e individual dos trabalhadores. Neste sentido é relevante fazer uma releitura dos conceitos de "fontes do direito" a partir do direito constitucional para que sejam examinadas as fontes do direito previdenciário. De plano é importante, outrossim, antecipar que a Constituição é a fonte primária do direito previdenciário. Também, é relevante fazer a contextualização das convençôes e acordos coletivos - com a abrangência históricoconceitual das negociaçóes coletivas, desde a perspectiva de superação do paradigma do contrato individual de trabalho até a definição dos contornos específicos dos contratos coletivos, tanto no direito estrangeiro, quanto no direito brasileiro como exame da vigência e a eficácia dos contratos coletivos de trabalho. Ademais, também serão referenciadosos princípios que norteiam as convençóes e os acordos coletivos do Trabalho, sempre com a preocupação metodológica de eleição dos princípios que mais estão alinhados ao objeto deste trabalho. Neste sentido, foram eleitos os princípios da ultratividade, da norma mais favorável, da dignidade humana e da vedação do retrocesso social.

Enfim, o que se pretende nesse trabalho é demonstrar a força cogente das normas previdenciárias nas convençóes e nos acordos coletivos de trabalho, pois sendo uma norma fundamental tem como fim promover o resgate do valor do trabalho e vincular toda ordem social aos fins a que elas foram adjudicados com a busca da justiça e do bem-estar sociais. 


\section{Fontes do Direito}

A convivência humana em sociedade faz surgir conflitos de interesses e, como consectário, impóe-se a normatização das condutas individuais a fim de assegurar a ordem e a paz social. As normas dispostas em conjunto e sistematicamente formam o que se denomina direito. Noberto Bobbio (2001, pp.170-176) ${ }^{1}$ assinala que o que se chama de direito é mais uma característica de certos ordenamentos normativos do que de certas normas. Parte-se da norma e chega-se ao ordenamento jurídico. Assim, norma jurídica é aquela que pertence a um ordenamento jurídico (BOBBIO, 1997, p.194)².

O poder é um elemento essencial ao conceito de fonte de direito.Este se diversifica em modalidades da forma do poder de decidir na experiência social. Existem quatro tipos de fontes de direito: a legal, que resulta do poder estatal de legislar; a consuetudinária, expressão do poder social inerente à vida coletiva e das formas de comportamento; a jurisdicional, que se vincula ao Poder Judiciário, por intermédio das sentenças e, por último, a fonte negocial, ligada ao poder que tem a vontade humana. De acordo com a doutrina de Miguel Reale, as fontes de direito "são sempre estruturas normativas que implicam a existência de decisão sobre seu conteúdo, ou seja, um poder de optar entre várias vias normativas possíveis". Para o jurista, o problema essencial que se lhe póe é o estudo daquilo que foi processado e formalizado, isto é, positivado numa lei, num costume, numa sentença, ou num contrato que, em seu ver, são as quatro fontes por excelência do direito. Sobre a relação mútua entre validade e eficácia das fontes do direito, sem o que não se pode falar em positividade do direito, Miguel Reale (1994, p.1-15) admite que a fonte refere-se mais propriamente às condiçóes de validade dos preceitos jurídicos postos por ela, ao passo que os modelos jurídicos, como conteúdo das fontes, representam a atualização ou projeçáo destas no espaço e no tempo social, no plano da eficácia, ou do procedimento. Nessa linha de entendimento, a fonte de direito implica no conjunto de pressupostos de validade que

1 Em seu livro Teoria da Norma Jurídica, Norberto Bobbio enfrenta a questão do caráter jurídico da norma e aduz que num sistema normativo busca-se salvaguardar a lei da erosão das açóes contrárias. Sua teoria do ordenamento jurídico constitui uma integração da teoria da norma jurídica. BOBBIO, Norberto. Teoria da Norma Jurídica. Tradução Fernando Pavan Baptista e Ariane Bueno Sudatti. Ed. Edipro. Bauru: São Paulo. 2001, pp. 170-176.

2 Para Bobbio, as normas jurídicas nunca existem isoladamente, mas sempre em um contexto de normas com relaçóes particulares entre si e a este contexto de normas é o que se costuma chamar de ordenamento. Acrescenta, ainda, que por mais numerosas que sejam as fontes do direito num ordenamento complexo, tal ordenamento constitui uma unidade pelo fato de que, direta ou indiretamente, com voltas mais ou menos tortuosas, todas as fontes do direito podem ser remontadas a uma única norma. Para ele, um ordenamento é completo quando o juiz pode encontrar nele uma norma para regular qualquer caso que se lhe apresente. Podemos dizer que um ordenamento é completo quando jamais se verifica o caso de que a ele não se podem demonstrar pertencentes nem certa norma nem a norma contraditória. BOBBIO, Norberto. Teoria do Ordenamento Jurídico. Tradução de Maria Celeste C. J. Santos. 10a Ed. Brasília: Editora Universidade de Brasília, 1997.p. 134. 
deve ser obedecido para que a produção de prescrições normativas seja considerada obrigatória e assim, se projete na vida social e conduza a momentos diversos das atividades da sociedade civil e do Estado.

\subsection{Fontes do Direito Constitucional}

A Constituição é a fonte máxima e suprema do direito constitucional nos países em que não pode ser modificada por lei ordinária, mas somente por processos especiais estabelecidos constitucionalmente. É a Constituição o instrumento das decisóes políticas fundamentais da nação e nela se exprimem as normas jurídicas relativas à estrutura do Estado, à competência de seus órgãos, seus fins essenciais, os limites de sua atuação e os direitos e deveres dos cidadãos. A Constituição não contém - nem pode conter -todas as normas, todas as regras e todos os princípios do direito constitucional e, por isso mesmo também, as leis ordinárias, os decretos, os regulamentos, as instruçóes estabelecem normas novas, não contidas na Constituição, o que revela, de modo imediato, uma parte do direito constitucional.

Mas se a Constituição é lei fundamental e suprema, leis, decretos e regulamentos devem com ela conformar-se, isto é, não poderão contrariá-la, nem explícita nem implicitamente. Só a Constituição não conhece norma jurídica que lhe seja superior.Daí dizer-se que Constituição é uma forma de produção originária do direito, pois que nela se estabelecem as normas fundamentais de um sistema jurídico e seencontra seu nascimento, sem apoio em qualquer norma positiva prévia. Todas as demais normas constituem produção jurídica derivada, pois vão buscar fundamento, ou seja, título de validez na Constituição, nos poderese nas competências por ela estabelecidos. Assim, leis, decretos, sentenças, atos administrativos, tratados, contratos e atos jurídicos praticados pelos particulares, tudo encontra fundamentos e títulos de validez na Constituição formal.

\subsubsection{Espécies Normativo-Jurídicas de Fontes de Direito}

$\mathrm{Na}$ doutrina de Miguel Reale (1994, p.22-25), já citada anteriormente, existem as seguintes espécies normativo-jurídicas: a legal, a consuetudinária, a jurisdicional e a negocial. Relevante para este trabalho destacar a importância dos costumes como fontes do direito do trabalho, por serem fontes dos direitos sociais e, nesse sentido, destaco os ensinamentos de Arnaldo Sussekind, que leciona que o costume tem lugar de relevância nas relaçóes de trabalho e caracteriza-se pelo comportamento do grupo social a respeito de determinadas situaçóes, por tempo suficiente para ingressar no mundo jurídico e pode ser invocado como regra jurídica reguladora de situaçóes não contempladas por outras fontes formais de direito; para contemplar disposiçóes legais convencionais e contratuais, quando compatível com a mesma; como fonte material de lei, convenção coletiva, sentença 
normativa, laudo arbitral ou regulamento de empresa, na regulamentação das condiçóes de trabalho (SUSSEKIND, 2002, p.125). Registre-se que com os contratos coletivos de trabalho e os regulamentos das empresas, antes de reconhecidos pelos sistemas legais de quase todos os países, eram considerados como direito consuetudinário. Hodiernamente se verifica um declínio na aplicação dos costumes nascidos na prática das atividades profissionais, porque suas manifestaçóes vêm sendo formuladas por leis, convençóes coletivas e regulamentos de empresa.

E, também, o poder negocial, mais especificamente, o contrato é, para Miguel Reale, fontes de norma jurídica, ainda que com eficácia restrita aos participantes da relação jurídicaque leva em consideração que o contrato tem força de lei entre as partes. Na visão de Reale há as seguintes características: a) manifestação de vontade de pessoas legitimadas a fazê-lo; b) forma de querer que não contrarie a exigida em lei e objeto lícito e possível; c) paridade entre os partícipes ou pelo menos uma devida proporçáo entre eles. Disso resulta o que se chama negócio jurídico, que consiste numa auto-regulamentação dos interesses particulares pelo ordenamento jurídico, oriundo da autonomia privada das partes contratantes (REALE, 1994, p.131).

Na atualidade, com maior ênfase no Estado Democrático de Direito, é cada vez mais reveladora a atuação do Direito através dos negócios jurídicos particulares e também coletivos, colocando à margem, na maioria das vezes, as fórmulas estatizantes do mundo jurídico, seja no campo nacional ou internacional. Exemplo dessa espécie de "revolução" na aplicação do Direito, a Constituição Brasileira de 1988 consagra,como fundamentos da ordem econômica, os princípios da livre iniciativa e da livre concorrência, a negociação coletiva entre trabalhadores e empregadores restando superada a assertiva de que o negócio jurídico só existe porque assim dispóe a lei, dando lugar ao seu nascimento como modelo jurídico autêntico e desprendido dos impedimentos e dificuldades criadas pelo legislador ordinário, que náo tem poderes para suprimi-lo do mundo jurídico, mas tão-apenas para regulá-los na medida dos imperativos da livre existência das múltiplas vontades autônomas concorrentes.

\subsection{Fontes do Direito Previdenciário}

Consideram-se fontes constitucionais do direito previdenciário as fontes filosóficas que se transformam em direito positivo. No direito brasileiro, pela definiçáo do artigo 193 da Constituição, há a seguinte expressão: "A ordem social tem como base o primado do trabalho e como objetivo o bem-estar e a justiça social" . A incumbência desse conjunto de princípios e normas é a de conduzir a sociedade ao estágio de bem-estar e justiça sociais sob o primado do trabalho. A expressão primado do trabalho foi utilizada nos tempos 
modernos pelo Papa João Paulo II, na célebre encíclica Laborem Exercens, de 1979. Essa encíclica define o trabalho como chave da questão social, seu componente essencial.

A fonte de direito previdenciário brasileiro, estampada no texto do artigo 193 da Constituição de outubro de 1988, serve também como critério de interpretaçâo de nossa disciplina. As normas do direito previdenciário objetivam concretizar o estágio do bem-estar e da justiça sociais. De outra parte, pode-se entender a expressáo fonte em duplo sentido: o formal e o material(BALERA, 2003, $p, 24)^{3}$.

\subsubsection{A Constituição como Fonte do Direito previdenciário}

A primeira fonte formal do direito previdenciário é a Constituição da República Federativa do Brasil, de 5 de outubro de 1988, que contém inúmeros dispositivos em matéria previdenciária que começa pelo artigo $6^{\circ}$ ao definir os direitos sociais. Nesse artigo, são direitos sociais, a saúde, a previdência e a assistência social.

De outra parte, o artigo $7^{\circ}$ da Carta Magna estabelece, em diversos dispositivos, alguns dos direitos previdenciários. Citam-se, ilustrativamente, os seguintes: inciso II, que confere direito ao seguro-desemprego; inciso VIII, que concede o direito ao $13^{\circ} \mathrm{sa}-$ lário para os aposentados e pensionistas; inciso XII, que outorga o salário-família aos dependentes dos trabalhadores de baixa renda; e incisos XVIII, XXV e XXVIII, salário maternidade, auxílio-creche e auxílio pré-escolar e seguro contra acidente do trabalho, respectivamente, dentreoutros. $\mathrm{O}$ artigo 10 da Constituição Federal atribui aos trabalhadores e empregadores a gestáo do sistema. E o sistema deve, por definição constitucional, ser administrado tanto pelo Estado como pelos trabalhadores e empresários. Ademais, o artigo 195 combinado com o artigo 149, parágrafo único, da Constituiçáo, estabelecem as fontes de financiamento do sistema de seguridade social. Toda a matéria de que tratam os artigos 194 e seguintes até o artigo 204 da Constituição são fontes constitucionais do direito previdenciário. É particularmente importante citar o artigo 194 e seu parágrafo único, que definem os princípios norteadores da Seguridade Social. ${ }^{4}$

3 Do ponto de vista formal, as fontes são os atos normativos que inovam na ordem jurídica e criam o direito. Fontes materiais também chamadas de fontes reais são os acontecimentos da vida que, qualificados juridicamente, produzem efeitos de direito. Os fatos da vida são apreendidos pelo direito e geram o direito sobre esses fatos, que são as relaçōes jurídicas. No direito positivo há uma rígida hierarquia entre as fontes, de tal sorte que existem normas mais importantes do que outras e que, por esse razão, prevalecem sobre as demais.

4 Constituição Federal (...) - Art. 194. A seguridade social compreende um conjunto integrado de ações de iniciativa dos Poderes Públicos e da sociedade, destinadas a assegurar os direitos relativos à saúde, à previdência e à assistência social. Parágrafo único. Compete ao Poder Público, nos termos da lei, organizar a seguridade social, com base nos seguintes objetivos: I - universalidade da cobertura e do atendimento; II - uniformidade e equivalência dos benefícios e serviços às populaçôes urbanas e rurais; III - seletividade e distributividade na prestação dos benefícios e serviços; IV - irredutibilidade 
A Constituição, portanto, é a primeira das fontes do direito previdenciário. A própria Magna Carta é que, na ordem normativa, estabelece as fonteslegislativas, o seguinte: "O processo legislativo compreende a elaboração de emendas da Constituição, leis complementares, leis ordinárias, leis delegadas, medidas provisórias, decretos legislativos e resoluçóes".

\section{Conceito de Negociação Coletiva}

Segundo a Convenção no 154 , de 1981, aprovada na 67a reunião da Conferência Internacional do Trabalho, entrou em vigor no plano internacional em 11.08.1983, aprovada no Brasil pelo Decreto Legislativo n. 22, de 12.05.1992, do Congresso Nacional, ratificada em 10.07.1992 e promulgada pelo Decreto n. 1.256, de 29.09.1994, com vigência nacional, a partir de 10.07.1993 define no art. 2 a expressão "negociação coletiva" como,

todas as negociaçóes que tenham lugar entre, de uma parte, umempregador, um grupo de empregadores ou uma organização ou váriasorganizaçôes de empregadores, e, de outra parte, uma ou várias organizaçóes de trabalhadores, com fim de:a) fixar as condiçóes de trabalho e emprego; oub) regular as relaçóes entre empregadores e trabalhadores; ouc) regular as relações entre os empregadores ou suas organizações e uma ouvárias organizaçóes de trabalhadores, ou alcançar todos estes objetivos de uma só vez ${ }^{5}$.

Como se vê, a definição de OIT não se chega efetivamente a indicar o que seria negociação coletiva, no entanto, sua pretensão é limitar o campo da negociação coletiva no âmbito das relaçóes de trabalho, do ponto de vista de seus sujeitos e de sua finalidade (BRITO FILHO, 200, p. 146). No conceito disposto no artigo supra da Convenção, do lado dos empregadores, os sujeitos são variados; pode ser um único empregador ou vários; pode ser uma organização de empregadores ou várias. Do lado dos trabalhadores, os sujeitos são mais restritos; limitam-se às organizaçóes de trabalhadores, no singular ou no plural.

Sob o plano doutrinário, neste mesmo sentido, deve-se mencionar a definição de Alfredo J. Ruprechet (1995, p.265):

do valor dos benefícios; V - equidade na forma de participação no custeio; VI - diversidade da base de financiamento; VII - caráter democrático e descentralizado da administração, mediante gestão quadripartite, com participação dos trabalhadores, dos empregadores, dos aposentados e do Governo nos órgãos colegiados. (Redação dada pela Emenda Constitucional no 20, de 1998)

5 Convençáo no 154 , de 1981, aprovada na $67^{\text {a }}$ reunião da Conferência Internacional do Trabalho, entrou em vigor no plano internacional em 11.08.1983, aprovada no Brasil pelo Decreto Legislativo n. 22, de 12.05.1992, do Congresso Nacional, ratificada em 10.07.1992 e promulgada pelo Decreto n. 1.256, de 29.09.1994, com vigência nacional, a partir de 10.07.1993, art. $2^{\circ}$. 
Negociação coletiva é o processo tendente à superação do conflito coletivo. Dela devem necessariamente participar o sindicato dos trabalhadores, salvo as negociaçôes estiverem voltadas à celebração de acordo coletivo que, por definição prescinde da participação do sindicato patronal.

São duas as finalidades da negociação coletiva: 1) fixar condiçôes individuais de trabalho e 2) estabelece as condiçôes para o relacionamento entre aqueles que se engajam nas relaçóes coletivas de trabalho.Nesse sentido, se entende que a expressão "negociação coletiva" disposta no art 20 da Convenção 154, da Organização Internacional do Trabalho, compreende todas as negociaçóes que têm lugar entre um empregador, um grupo de empregadores, uma organização ou várias organizaçóes de empregadores, de um lado, e uma organização ou várias organizaçóes de trabalhadores, de outro lado, com o fim de: a) fixar as condiçóes de trabalho e emprego; b) regular as relaçôes entre empregadores ou trabalhadores; c) regular as relaçôes entre empregadores ou suas organizaçóes e uma organização ou várias organizaçóes de trabalhadores, ou lograr todos esses fins concomitantemente.

Segundo José Carlos Arouca (2014, p.308),

a negociação pode frustrar-se e, muitas das vezes, ainda mais agora, quando se passa a admitir a flexibilização de direitos e às reivindicaçóes dos trabalhadores os empregadores contrapóem as suas. Desse modo, tendo presente no nosso ordenamento jurídico, negociação coletiva é o procedimento de tratativas entre um ou mais sindicatos de empregadores ou uma ou mais empresas com o propósito de conciliar o trabalho e o capital a partir das reivindicaçôes de um ou outro destinadas a completar as relaçóes de trabalho no âmbito das respectivas representações ou dos contratos de trabalho.

Desta forma, pode-sesistematizar os conceitos acima descritos com a ideia ampla de que a negociação coletiva consubstancia a principal manifestação auto-compositiva de solução dos conflitos pelo consenso e autonomia das partes conflitantes, cujos principais meios de exteriorização são a convenção e o acordo coletivo de trabalho.

\subsection{Acordos e Convenções Coletivas do Trabalho}

As Convençóes Coletivas de Trabalho e os Acordos Coletivos de Trabalho ${ }^{6}$ são, indubitavelmente, as mais importantes fontes imperativas de produçáo coletiva autônoma, profissional, consoante divisão proposta por Gomes e Gottschalk (2000, p. 33 e ss), do

6 Os acordos coletivos de trabalho foram inseridos no ordenamento jurídico brasileiro a partir do advento do Decreto-lei n. 229, de 28 de fevereiro de 1967, que incluiu o $\$ 1^{\circ}$ ao artigo 611 da Consolidação das Leis do Trabalho. 
Direito do Trabalho, prestando-se como instrumentos de consagração do denominado pluralismo jurídico, identificado por Amauri Mascaro Nascimento(2000, p.130-133) como "princípio fundante dos ordenamentos sociais", expresso na "teoria do direito social". Com o propósito de encontrar solução satisfatória para os problemas entáo decorrentesde dois ramos do Direito, o Direito do Trabalho e o Direito Internacional, Gurvitch (1931, p.130), um dos fundadores da teoria do direito social, já em 1931, numa de suas obras clássicas,sustentava a necessidade, para ele indispensável, de "fundamental revisão da teoriadas fontes do direito positivo", argumentando que "o estado atual do Direito do Trabalhoé caracterizado, antes de mais nada, pelo papel crescente do direito extra-estatal e inoficial que emana dos grupos espontâneos de interessados e os seus acordos".

Primeiramente, no que se refere à denominação dada a esta fonte formal de Direito do Trabalho não existe uniformidade, tendo, inclusive, o Brasil adotado mais de uma denominação. Na Constituição de 1934 foi adotada a denominação convenção que, ulteriormente, passou para contrato coletivo na Constituição de 1937, por se inspirar no modelo fascista italiano e retornou para convenção através da Constituição de 1946.

A Constituição de 1988, em seu artigo 7º, inciso XXV, adotou a denominação convenção coletiva, como já figurava na Consolidação das Leis do Trabalho, desde o advento do Decreto-lei no 229, de 1967. O referido decreto-lei modificou o texto consolidado primitivo e alterou a expressão "contrato coletivo de trabalho" por "convenção coletiva de trabalho", tal como hodiernamente vigora o artigo 611, que disciplinou uma nova fórmula compositiva: o "acordo coletivo de trabalho". Além disso, alterou a expressão estipulam condiçóes que regerão as relaçóes individuais de trabalho, no âmbito da respectiva representação" por "estipulam condiçóes de trabalho aplicáveis no âmbito das respectivas representaçóes, às relaçóes individuais de trabalho.

Neste diapasão, pode-se concluir que a convenção e contrato coletivo têm, efetivamente, o mesmo sentido e significado. De qualquer modo, contrato ou convenção coletiva, segundo Orlando Gomes (GOMES, GOTTSCHALK, (2000, p.585-586) “(...) foi a instituição que, pela primeira vez, permitiu aos trabalhadores influir, real e positivamente, na determinação das condiçóes de trabalho.”

\subsubsection{Conceito de Convenção e Acordo Coletivo}

Existem diversas formas de definir o ajuste firmado entre empregados e empregadores no plano coletivo.A Organização Internacional do Trabalho, por meioda Recomendação no 91, de 1951, definiu o contrato coletivo como:

todo contrato escrito relativo às condiçóes de trabalho e emprego, celebrado entre um empregador, um grupo de empregadores ou uma ou várias organizaçôes de empregadores, por uma parte e, por outra, uma ou 
várias organizaçóes representativas de trabalhadores ou, na ausência de tais organizaçôes, representantes dos trabalhadores interessados, devidamente eleitos e autorizados por esses últimos, de acordo com a legislação nacional.

No Brasil, com a promulgação da Constituição de 1988, as convenções e os acordos coletivos de trabalho passaram a ser expressamente garantidos no artigo $7^{\circ}$, inciso XXVI. No entanto, foi através do seu artigo $1^{\circ}$, do Decreto-lei no 21.761 , de 23 de agosto de 1932, norma precursora, que a convenção coletiva de trabalho foi conceituada e regulamentada - ressalva-se que a Lei no $19.770 / 1931$ previa a celebração de convençóes ou contratos de trabalho, sem, contudo, conceituá-los - e cuja denominação somente foi adotada pela Consolidação das Leis do Trabalho, a partir de 1967, com o advento do Decreto-lei no 229. Neste sentido, o legislador instituiu avanços no Direito Coletivo e introduziu três modificaçóes significativas: a) concedeu eficácia erga omnes a todos os integrantes das categorias envolvidas, independentemente de decisão pelo Ministério do Trabalho, Indústria e Comércio; b) possibilitou a formalização de pacto coletivo no plano de empresas ("acordo coletivo"); c) deixou claro que as normas convencionais concorrem, paralelamente, com outras fontes formais do Direito, notadamente a autonomia privada dos contratantes.

$\mathrm{Na}$ acepção legal, convenção coletiva de trabalho, propriamente dita, é o instrumento celebrado entre os sindicatos representativos das categorias profissionais e econômicas, ou seja, é o diploma negocial de natureza intersindical. $\mathrm{O}$ acordo coletivo de trabalho é o meio negociado entre os sindicatos representativos das categorias profissionais e uma ou mais empresas da correspondente categoria economia, ou seja, de menor abrangência.

Amauri Mascaro Nascimento (2003, p.1178) entende que a distinção entre os dois níveis de negociação coletiva está relacionada ao "âmbito de aplicação", pois as convençôes coletivas de trabalho emergem aplicáveis a todos os empregadores e a todos os empregados integrantes das categorias envolvidas, sejam associadas ou não, enquanto os acordos coletivos resultam em campo de aplicação menor, eis que restritos a uma ou mais empresas que participaram da negociação. Por fim, Segadas Vianna (VIANNA, SUSSEKIND, MARANHÃO, TEIXEIRA,2005,vol. II, p.164), com base na legislação brasileira, define convenção coletiva de trabalho como "um ato legislativo elaborado por entidades sindicais e por via convencional, visando a regular e estipular as condiçóes para as relaçóes individuais de trabalho".

\subsubsection{Vigência, Validade e Eficácia dos Contratos Coletivos do Trabalho e Previ- denciários}

A vigência "revela a qualidade, ou o estado do que está em vigor, permanece efetivo, exerce toda sua força, ou se encontra em plena eficácia, ou efeito."HUECK, NIPPERDEY, 
1963, p. 302-315).No que se refere à concepção formal da vigência, a problemática se revela no tempo de atuação e existência jurídica da norma, cuja qualidade a torna de observância obrigatória, ou seja, vigência é o atributo que determina o tempo em que a norma começará a viger e, portanto, poderá ser exigível.

Miguel Reale (1987, p.78) não reduz o problema da vigência à mera concepção normativista, no seu entender, caracterizada pela legitimidade e competência pelo órgão emanador da regra; pela compatibilidade hierárquica com as normas subordinantes ou não; pela obediência a trâmites e procedimentos previstos no ordenamento jurídico em que se pretende inserir - mas, ao revés, exalta as exigências axiológicas que determinaram o aparecimento da regra jurídica, bem como as condiçôes fáticas suscetíveis de viabilizar sua eficácia social. Assim, Reale busca correlacionar o "fundamento" com a "vigência" e a "vigência” com a "eficácia”.

Para a legislação brasileira, a duração dos contratos coletivos de trabalho é estabelecida no art. $614, \$ 3^{\circ}$, da Consolidação das Leis do Trabalho, que prescreve: "Não será permitido estipular duração de Convenção ou Acordo superior a 2 (dois) anos". Logo, a única modalidade de contrato coletivo de trabalho admitida, de acordo com a sua duração, é a contratação por prazo determinado, com limitação temporal máxima, ao contrário de outros países que, de acordo com Magano, admitem "que a convenção se celebre por prazo determinado como por prazo indeterminado (MAGANO, 1990, p. 34).

Dessa forma, devem as partes estabelecer sempre nos contratos coletivos a cláusula de duração com fixação de período máximo de dois anos para sua vigência, em virtude do preceito do art. $614, \$ 3^{\circ}$ da Consolidação das Leis do Trabalho, sob pena de nulidade, conforme art. 613 da CLT.Contudo, nada impede que as partes pactuem a retroavidade de seus efeitos ou a prorrogação de seu vencimento. Neste sentido, entende José Claudio Monteiro de Brito Filho (2007, p. 55), que o ajuste fixando prazo de duração superior a dois anos, não será nulo, apenas deverá ser adequado à imposição legal, tendo a duração limitada ao prazo máximo estabelecido em lei. Contrariamente, entende Mônica Sette Lopes (1998, p.192) que "a disposição legal sobre a duração máxima do contrato coletivo tem natureza supletiva, só sendo aplicada em inexistência de disposição convencional a respeito, pelo que as partes poderiam ajustar prazo superior ao estabelecido na lei."Também a jurisprudência consolidada entende que é inválida a cláusula naquilo que ultrapassa o prazo total de dois anos e o instrumento coletivo originário por prazo indeterminado.

Entretanto, existem decisóes da $1^{\text {a }}$ Turma do Tribunal Superior do Trabalho nos Processos nos. RR 1205/2002-043-12-40 (DJ 27.10.2006) e RR-1248/02-043-12-00.0 (DJ $31.10 .2007)$, que entenderam que não é prejudicial ao empregado um acordo coletivo ser fixado com prazo superior a dois anos, inclusive porque não há restrição no texto constitucional, As referidas decisóes praticamente reinterpretam a Orientação Jurisprudencial $n^{\circ}$. 322, da SBDI-1 do Tribunal Superior do Trabalho, não obstante essa Orientação 
dispor expressamente que é de dois anos o prazo máximo para a vigência de contratos coletivos de trabalho. $\mathrm{O}$ argumento utilizado para reinterpretar a Orientação é de que se assenta esta em precedentes em que houve prorrogação por tempo indeterminado, com prejuízo para os trabalhadores, ou seja, fundado na regra da norma mais favorável.

Ainda sobre a duração, observa-se que inexiste vedação legal ao estabelecimento de duração diferenciada para determinadas cláusulas, ou seja, não é vedado que parte das cláusulas do acordo tenha uma duração e o restante do instrumento outra, como, por exemplo, pode-se estipular convenção com duração de dois anos, salvo em relaçáo às cláusulas relativas a salário e remuneração, que podem ter outra duração, qual seja, um ano.

Em relação à vigência, o artigo 614, $\$ 1^{\circ}$ da Consolidação das Leis do Trabalho estabelece que os contratos coletivos de trabalho entram em vigor 3 (três) dias após a data de sua entrega para fins de registro e arquivamento. Logo, muito embora possa ser afirmado que somente será exigido o cumprimento de norma prevista no contrato coletivo passados três dias do pedido de registro, não significa que as partes não possam fixar outra data para a entrada em vigor, posterior a três dias, ou até anterior. Porém, destaca-se que o prazo legal é para a exigibilidade, não para a data de produção de efeitos, assim, se for concedido, por exemplo, um reajuste salarial, este será devido a partir da data acordada pelas partes, no entanto, somente poderá ser cobrado do empregador a partir da entrada em vigor do contrato coletivo de trabalho. Por fim, conforme entendimento do Tribunal Superior do Trabalho não poderá ocorrer, todavia, a entrada em vigor com efeito retroativo que venha em prejuízo dos trabalhadores, sob pena de ferir direito adquirido, in verbis:

RECURSO DE REVISTA - TURNO ININTERRUPTO DE REVEZAMENTO - ACORDO COLETIVO - CLÁUSULA QUE DISPÓE SOBRE SITUAÇÃO PRETÉRITA JÁ CONSUMADA NO TEMPO - INEFICÁCIA. As convençóes e acordos coletivos são instrumentos normativos autônomos, resultantes de negociaçáo coletiva, por meio da qual se celebra um pacto de vontade com vigência limitada no tempo, cujas cláusulas vigoram pelo período respectivo, de modo que, apenas no período de vigência do acordo coletivo, prevalece a jornada de trabalho em regime de turnos ininterruptos de revezamento superior àquela estabelecida no art. 7o, XIV, da Constituição Federal. No mesmo diapasão, cláusula dispondo sobre situação já consumada no tempo, visando emprestar validade formal ao regime de turnos ininterruptos com efeitos pretéritos, esbarra, quanto à eficácia, no que se contém do art. $614, \$ 3^{\circ}$ da CLT, art. $6^{\circ}$ da LICC e art. 5\%, inciso XXXVI da CF/88. ${ }^{7}$

7 TST - 1a Turma, Processo n. RR 701010/2000, julgamento em 1º.11.2006, Relator Ministro Vieira de Mello Filho, DJ 17.11.2006. 
Quanto à validade, pode se dizer que em sentido amplo, a validade da norma pode ser classifica em validade constitucional, formal e material. A validade constitucional indica que a norma foi elaborada conforme os preceitos constitucionais. A validade formal exprime seu regramento com a observância dos procedimentos legais. Já a validade material situa-se no âmbito da matéria objeto de elaboraçáo.Do ponto de vista legal, validade e vigência podem coincidir, pois significa que durante o prazo de validade a norma é vigente. Entretanto, nada impede que uma norma formalmente válida tenha sua vigência postergada por sua fonte instituidora, conforme preconiza o caput do artigo $1^{\circ}$ da Lei de Introdução às Normas do Direito Brasileiro, ou uma norma vigente cuja validade está sendo questionada, por suposta desconformidade com as regras impostas pelo sistema para sua produção (GONÇALVES, 2008, p.88).

No entanto, forçosa é a distinção entre a validade que diz respeito à conformação da norma elaborada às regras do sistema e a vigência, ao revés, refere-se ao tempo de duraçáo da norma. Assim, não se pode negar que uma norma válida e vigente se reveste de aptidão para produzir efeitos (eficácia). Entretanto, segundo a mesma deve haver possibilidade de uma norma revogada e, portanto, inválida e não mais vigente, produzir efeitos jurídicos vinculantes, transcendendo aos limites formais e temporais, sendo este fenômeno denominado de "ultratividade" da norma.

Sobre este tema havia entendimento tradicional firmado pela jurisprudência trabalhista durante mais de três décadas e apoiado por grande parte da doutrina que aduzia que a eficácia jurídica dos contratos coletivos de trabalho estava limitada ao prazo de sua vigência, logo os direitos e obrigações normativas não se integrariam, como direitos adquiridos, aos contratos de trabalho (ZANGRANO, p.621).A justificativa deste entendimento era de que as condiçóes de trabalho são naturalmente mutáveis, logo os negócios jurídicos normativos que as regulamentam devem estar sempre marcados pela modificabilidade. Em razão disso, este entendia que seria extremamente prejudicial que as normas coletivas se "petrificassem", como direitos adquiridos.

No âmbito do direito espanhol, o Estatuto dos Trabalhadores prevê a cessação dos efeitos das cláusulas obrigacionais ao término da vigência da convenção. No entanto, quanto às cláusulas normativas, inexiste prorrogação automática, ao termo final da convenção, matéria a ser regulada pelo próprio diploma negocial. Graciela Giuzio, ao abordar a questáo da ultratividade em seu país, Uruguai, onde não existe norma legal alguma que regule esta matéria, concluiu pela continuidade da aplicação das cláusulas normativas, mesmo após a extinção do contrato coletivo, inclusive para os trabalhadores admitidos após dita extinção, o explicaria pelo princípio da igualdade e pela transformação do conteúdo do contrato em usos e práticas profissionais (RODRIGUEZ, 2000, p.110).

No Brasil não há legislativamente o fenômeno da ultratividade. Isso ocorreu após a época que prevaleceu a ultratividade em virtude do artigo $1^{\circ}, \$ 1^{\circ}$ da Lei ${ }^{\circ} 8.542 / 92$, lei 
esta revogada pelo artigo 18, da Medida Provisória no ${ }^{\circ}$ 1.079, de 28.7.95, sucessivamente reeditada.Destaca-se que, em 02 de julho de 1998, o Ministro Marco Aurélio, do Superior Tribunal Federal, concedeu liminar na ADIn n. 1.849-0-DF, que suspendeu a eficácia do artigo 19, da Medida Provisória n. 1.620, de 10 de julho de 1998, que substituía o artigo 18 da MP n. 1.079/95, que consagrava provisoriamente a ultratividade.

No entanto, o governo não aceitou o entendimento do STF - Supremo Tribunal Federal, e transformou a MP - Medida Provisória n. 2.074/73 na Lei no 10.192 , de 14 de fevereiro de 2001. O artigo 18 dessa lei revogou o artigo $1^{\circ}$, $\$ 1^{\circ}$ da Lei no 8.542/92.A jurisprudência do Tribunal Superior do Trabalho vinha até 2012 rechaçando a ultratividade, conforme se verifica pelo acórdão abaixo:

RECURSO DE REVISTA. NORMAS COLETIVAS. ULTRATIVIDADE. ARTIGO. 1० DA LEI No 8.542/92. Com a revogação do comando legal insculpido no $\$ 1^{\circ}$ do artigo $1^{\circ}$ da Lei no $8.542 / 92$ - o qual expressamente previa que as cláusulas dos acordos, contratos e convençôes coletivas de trabalho integravam os contratos individuais de trabalho e somente poderiam ser reduzidas ou suprimidas em posterior acordo, convenção ou contrato coletivo de trabalho - a partir de julho de 1995, com a edição da Medida Provisória no 1.079 e suas sucessivas reediçóes, as quais culminaram com o advento da Lei $\mathrm{n}^{\circ} 10.192$, de 14/02/2001, inexiste respaldo legal para o reconhecimento da ultratividade da norma convencional. Inteligência da Súmula no 277 do TST. (Processo $n^{\circ}$. TST-RR- 705035-56.2000.5.05.5555, Relator Juiz Convocado: Luiz AntonioLazarim, Data de Julgamento: 04/10/2006, 6a Turma, Data de Publicação: DJ 20/10/2006).

Esse rechaço se dava porque de acordo com o artigo $614, \$ 3^{\circ}$ da Consolidação das Leis do Trabalho, as normas coletivas de trabalho devem ter vigência limitada a, no máximo, 2 anos, tendo inclusive jurisprudência trabalhista consolidada, OJ SBDI-1 n. 332, o que não admite vigência indeterminada das referidas convenções. No entanto, o Tribunal Superior do Trabalho, contradizendo sua própria jurisprudência consolidada, em 14 de setembro de 2012, durante a realizaçáo da 2a Semana do TST, reformou completamente a Súmula n. 277 de sua jurisprudência consolidada, embora sem qualquer precedente, admitindo uma "ultratividade geral por tempo indeterminado" das normas coletivas de trabalho, que passou a ser redigida da seguinte forma:

CONVENÇÃO COLETIVA DE TRABALHO OU ACORDO COLETIVO DE TRABALHO. EFICÁCIA. ULTRATIVIDADE. As cláusulas normativas dos acordos coletivos ou convenções coletivas integram os contratos individuais de trabalho e somente poderão ser modificadas ou suprimidas mediante negociação coletiva de trabalho.

Carlos Zangrando (2013, p.622) defende que se está diante de um vetusto entendimento que lança o Direito Coletivo do Trabalho de volta ao comodismo das décadas 
anteriores a promulgação da Constituição da República de 1988 e que contribuiu, negativamente, para a melhoria das relaçôes trabalhistas no país.A afirmação do referido autor se dá porque com a promulgação da Constituição de 1988 as convençóes e os acordos coletivos de trabalho passaram a ser reconhecidos como fontes formais de direitos e obrigaçóes, de acordo com artigo 7o, inciso XXVI.Outrossim, para o referido autor, quando o Tribunal Superior do Trabalho entende pela ultratividade geral e indeterminada das normas coletivas de trabalho, em especial das cláusulas normativas, uma vez que as cláusulas econômicas normalmente se exaurem com sua aplicação, estaria retrocedendo o Direito Coletivo de Trabalho de volta a imobilidade, inércia e "uniformidade", sendo, inclusive, desfavorável ao trabalhador que não terá direito à alteração de benefícios bem como à implantação de novos benefícios será retraída, pois as empresas terão receio de ter custos acima do planejado.

Sobre a alteração da redação realizada pelo Tribunal Superior do Trabalho na Súmula n. 277, há, ainda, a questão jurídica da validade e da eficácia dessa alteração sumular, pois ao rever, cancelar ou alterar uma súmula de jurisprudência uniforme, é necessário seguir os trâmites previstos no artigo 168 do Regimento Interno do Tribunal Superior do Trabalho e é necessária sua aprovação pelo Tribunal Pleno (artigo 62, RITST). Ocorre que, no caso desta súmula, não foram indicados precedentes necessários para a alteração. Além disso, de acordo com o artigo 614, $\$ 3^{\circ}$ da Consolidação das Leis do Trabalho, há ordem expressa que a eficácia temporária de acordos e convençóes coletivas de trabalho somente poderia ser admitida mediante lei que assim determinasse. Logo, no presente caso, a orientação jurisprudencial padece de suporte positivo, retirando-lhe, assim, toda a eficácia, pois não observou nenhuma das exigências previstas.

Entretanto, mesmo que não tenham sido observadas as exigências previstas na Consolidação das Leis do Trabalho e no Regimento Interno do Tribunal Superior do Trabalho, retirando, assim, a eficácia da jurisprudência do TST, a doutrina entende que há uma hipótese de ultratividade da norma coletiva de trabalho, quando trouxer vantagem, ou direito individual adquirido. Nesse caso, a denominada ultratividade excepcional da cláusula normativa do negócio coletivo vigorará mesmo depois de expirado seu prazo de vigência, conforme previsão da OJ SBDI-1 n. 41, in verbis,

OJ SBDI-1 n. 41. ESTABILIDADE. INSTRUMENTO NORMATIVO. VIGÊNCIA. EFICÁCIA. Preenchidos todos os pressupostos para a aquisição de estabilidade decorrente de acidente ou doença profissional, ainda durante a vigência do instrumento normativo, goza o empregado de estabilidade mesmo após o término da vigência deste.

Neste diapasão, pode-se afirmar que embora a nova redação da Súmula n. 277 seja juridicamente incapaz, pois não obedeceu ao Regimento Interno do Tribunal Superior do Trabalho. Quanto à alteração da súmula, excepcionalmente, há ultratividade na eficácia 
das normas coletivas de trabalho quando esta trouxer vantagens ou direito individual adquirido ao trabalhador.

\subsubsection{Princípios que Norteiam os Acordos e as Convenções Coletivas do Traba- Iho e Previdenciários}

Quando o intérprete ou aplicador da lei estiver diante de mais de uma norma jurídica, autônoma ou heterônoma, ainda que de diferentes hierarquias, aplicáveis a um ou mais fatos ocorridos numa relação laboral, dever-se-á escolher a que conceda maior favorabilidade ao empregado, sob os aspectos qualitativos ou quantitativos. O artigo 619 da Consolidação das Leis do Trabalho consagra este princípio preceituando que nenhuma disposição de contrato individual de trabalho que contrarie normas de convenção ou acordo coletivo de trabalho poderá prevalecer na execução do mesmo, sendo considerada nula de pleno direito. Além disso, o artigo 620 da CLT (Consolidação das leis do trabalho) prevê que as condiçóes estabelecidas em convenção quando mais favoráveis, prevalecerão sobre as estipuladas em acordo (ZANGRANO, 2013, p. 295).

O princípio da norma mais favorável encontra-se claramente demonstrado na Constituição de 1988, através de dois dispositivos: o primeiro encontra-se nos "Direitos Sociais", inserido no Capítulo II do Título II (“Dos Direitos e Garantias Fundamentais"), que dispóe que as diversas vantagens e proteçóes trabalhistas arroladas no art. $7^{\circ}$ constitucional são “(...) direitos dos trabalhadores urbanos e rurais, além de outros que visem à melhoria de sua condição social (...)". O segundo encontra-se no Capítulo I do mesmo Título II ("Dos Direitos e Garantias Fundamentais"), fixado no $\$ 2^{\circ}$ do artigo 5o, que prevê que "os direitos e garantias expressos nesta Constituição não excluem outros decorrentes do regime e dos princípios por ela adotados, ou dos tratados internacionais em que a República Federativa do Brasil seja parte”.

Registre-se ainda que, embora exista hierarquia nas fontes do direito do trabalho, esta é flexível, sendo atraída sempre para a norma mais benéfica ao trabalhador. No direito do trabalho não há rigidez hierárquica absoluta, visto que sempre que houver duas ou mais fontes distintas, deverá ser aplicada a que mais beneficia o trabalhador, na maior amplitude possível.Neste sentido, leciona Amauri Mascaro Nascimento (2009, p.89) que "na pirâmide normativa da hierarquia das normas jurídicas trabalhistas o vértice aponta para a norma que assegurar a melhor condição para o trabalhador, segundo uma dinâmica que não coincide com a distribuição estática de leis em graus de hierarquia, do direito comum".

O princípio da dignidade humana, nos dias atuais, é considerado "o epicentro de todo o ordenamento jurídico"(DELGADO,2013, p.154), visto que foi alçado a núcleo dos sistemas constitucionais mais democráticos.A Declaração Universal dos Direito do 
Homem, de 10.12.1948, foi uma das pioneiras referências a tratar do princípio da dignidade da pessoa humana. Nesta declaração trazia a dignidade da pessoa humana "como base da liberdade, da justiça e da paz.No Brasil, a primeira Constituição a mencionar o tema foi a de 1946. Entretanto, à dignidade somente foi relacionada ao trabalho e de modo restrito: "A todos é assegurado trabalho que possibilite existência digna(...)", dispunha o artigo 145, parágrafo único. Além disso, esta não continha status de fundamento ou princípio à dignidade humana na ordem juspolítica e social do país.

As Constituições de 1967 e 1969 mantiveram a menção à dignidade da pessoa humana, limitada à área de trabalho. Somente com a Constituição de 1988, a dignidade da pessoa humana alcançou de fato o status de núcleo do sistema constitucional do país e de núcleo de seu sistema jurídico, político e social. Assim, a dignidade passou a ser não só princípio, mas também princípio fundamental de todo o sistema jurídico.

No artigo $1^{\circ}$ da Constituição de 1988, parte que trata dos "princípios fundamentais", foi estabelecido que a"República Federativa do Brasil, formada pela união indissolúvel dos Estados e Municípios e do Distrito Federal, constitui-se em Estado Democrático de Direito e tem como fundamentos: (...)III - a dignidade da pessoa humana”. Já no artigo $3^{\circ}$, está insculpido que " constituem objetivos fundamentais da República Federativa do Brasil: I - construir uma sociedade livre, justa e solidária”, ou seja, este traz os três requisitos essenciais de garantia da dignidade da pessoa humana.

Além desses, ao tratar da "Ordem Econômica e Financeira" a Constituição de 1988 também se reportou à dignidade da pessoa humana no artigo 170 , ao estabelecer que "a ordem econômica, fundada na valorização do trabalho humano e na livre iniciativa, tem por fim assegurar a todos existência digna, conforme os ditames da justiça social (...)". A carta constitucional, ao tratar da "Ordem Social" firmou uma das dimensóes essenciais da dignidade da pessoa humana, sua dimensão social: "A ordem social tem como base o primado do trabalho, e como objetivo o bem-estar e a justiça sociais".Logo, pode-se concluir que a Constituição de 1988, incorporou o princípio da dignidade da pessoa humana em seu núcleo, conferiu-lhe status multifuncional, assegurou-lhe abrangência a toda a ordem jurídica a todas as relaçóes sociais e garantiu-lhe amplitude de conceito, de modo a ultrapassar sua visão estritamente individualista em favor de uma dimensão social comunitária de afirmação da dignidade humana..

O princípio da vedação do retrocesso indica que a ordem jurídica encontra-se obstada a criar ou ratificar normas e institutos que concretizem ou instiguem a piora ou degradação do patamar civilizatório atingido, em certo momento histórico, pelas condiçóes sociais caracterizadoras de certa sociedade e Estado, ou seja, há através desse princípio uma proibição a criação ou ratificação de normas jurídicas que propiciem o retrocesso social em determinada sociedade civil e sociedade política. O princípio da vedaçáo do retrocesso social influencia muito na estruturaçáo e no desenvolvimento do ramo do Direito 
do Trabalho, em virtude desse ramo jurídico especializado consistir em um dos principais instrumentos existentes de elevação das condiçóes de contratação e regência da força de trabalho no sistema capitalista (DELGADO, 2013, p.184).

A ideia da proibição do retrocesso está ligada ao pensamento do Canotilho (1998, p.734), que estabelece as tarefas de ação futura do Estado e à sociedade com a finalidade de dar maior alcance aos direitos sociais e diminuir as desigualdades. Em razão disso tanto a legislação como as decisóes judiciais não podem abandonar os avanços que se deram ao longo desse anos de aplicação do direito constitucional com a finalidade de concretizar os direitos fundamentais. Nesse sentido, para Canotilho,

se fala também de cláusulas de proibição de evolução reacionária ou de retrocesso social (ex. consagrados legalmente as prestaçóes de assistência social, o legislador não pode eliminá-las posteriormente sem alternativas ou compensaçóes, reconhecido, através de lei o subsídio de desemprego como dimensão do direito do trabalho, não pode o legislador extinguir este direito, violando o núcleo essencial do direito social.

Segundo Mauricio Godinho Delgado (2013, p. 186) este princípio poderia compreender a diretriz de maneira mais ampla, a fim de abranger inúmeras dimensôes, ou seja, não somente a social, mas também a política, a econômica e até mesmo a dimensão cultural. No entanto, o alargamento deste conceito produziria um enfraquecimento do princípio, pois se tornaria tão abrangente que deflagraria avalassadoramentea resistência à sua própria validade cientifica, por ser inviável, do ponto de vista prático, a não ocorrência, em sucessivos momentos históricos, de algum refluxo na economia, na cultura, nas instituições políticas etc. Esse princípio tem fundo no Direito Internacional do Trabalho, lá demarcando sua presença antes de ingressar no ordenamento jurídico brasileiro, visto que somente ingressou no Brasil com a promulgação da Constituição de 1988.

No que se refere ao plano de origem existencial, o princípio baseia-se em dois fundamentos principais: a circunstância de terem natureza de direitos humanos os direitos sociais trabalhistas, ao lado da própria estrutura histórica, conceitual, lógica e teleológica da Organização Internacional do Trabalho, como órgão e instrumento de afirmação e aperfeiçoamento dos direitos sociais trabalhistas. Quanto ao primeiro fundamento, leciona Daniela Muradas Reis (2010), p.185): (...) as condiçóes mínimas de trabalho firmadas no plano internacional inserem-se no quadro das prerrogativas da pessoa humana por força de sua dignidade própria, integrando o rol dos direitos humanos, em sua dimensão econômica e social.Assim, em razão dessa qualidade especial incidiria uma "reserva implicita ao retrocesso no tocante à proteção ao trabalho" no contexto do Direito Internacional do Trabalho e seus diplomas normativos integrantes.Quanto ao segundo fundamento, também explicita Daniela Muradas Reis (2010, p.186) que, no plano das normas jurídicas trabalhistas, 
essa reserva implícita presente nas convenções internacionais de trabalho derivaria ainda da própria justificativa histórica de existência da Organização Internacional do Trabalho”, em virtude de esta instituição ser voltada estruturalmente para a busca da “(...) melhoria das legislaçóes nacionais, com fixação de condiçôes de trabalho mínimas aplicáveis aos trabalhadores.

$\mathrm{Na}$ Constituição de 1988, o presente princípio encontra-se implícito a diversas diretrizes constitucionais convergentes, tais como os princípios da dignidade da pessoa humana, da valorização do trabalho e do emprego, do bem-estar e das justiças sociais, da subordinação da propriedade à sua função socioambiental.Todavia, no artigo $5^{\circ}, \$ 2^{\circ}$ da Constituição de 1988 encontra-se expresso que os direitos e garantias expressos na Constituição não excluem outros decorrentes “(...) dos tratados internacionais em que a República Federativa do Brasil seja parte”. Diante o exposto, a Constituição evidencia que as diretrizes combinadas de não retrocesso, progressividade e da norma mais favorável, se destacam como firmemente próprias à seara dos direitos humanos, inclusive os direitos trabalhistas.

\section{O Sistema Jurídico de Previdência Social}

A Constituição Federal de 1988, após longa trajetória histórica, consagrou o direito à seguridade social como um direito fundamental que visa a contribuir para a erradicaçáo da pobreza, a redução das desigualdades sociais, dentro dos padróes que determinam a dignidade humana, assegurando a distribuição de renda e a promoção da justiça social.

A realização do bem comum é a própria efetivação do ideal de justiça social, com a materialização naquela lei relativa a situaçóes jurídicas específicas. O bem comum, no entanto, só se realiza num Estado Democrático de Direito na proporção em que se respeitem, dentre outros, os princípios fundamentais da segurança jurídica, da certeza jurídica, da irretroatividade das leis, do direito adquirido e do efeito imediato das leis, para cuja concretização otimizada é necessária à aplicação do princípio da proporcionalidade pelo poder público. Acresçam-se os ensinamentos do professor Wagner Balera (2009, p. 137) que assevera,

no ambiente da justiça social, no qual está garantida vida digna ao ser humano, o sistema atua como o organismo que identificando as necessidades de proteção dos seres humanos, trata de satisfazê-las com atuação sistêmica e coordenada de seus programas". Acrescenta, ainda, que "o cumprimento do objetivo da universalidade da cobertura e do atendimento, cume dos princípios fundamentais da seguridade social (art. 194, parágrafo único, inciso I, da Constituição) com a consequente concretização da justiça social em nossa pátria, está inscrito na ossatura própria 
do Estado Social de Direito, Estado que se organiza em função da pessoa e que quer conferir a todos uma existência digna.

\subsection{Seguridade Social: Conceito e Fundamento}

O professor Martins Fajardo (1985, p.11) considera a Seguridade Social, enquanto expressão jurídica, como um direito humano fundamental, pois é um sistema juridicamente organizado pelo Estado para o enfrentamento dos riscos sociais que promove a elevação dos níveis de bem-estar baseado em açóes solidárias e justas entre uma coletividade.

Como expressão sociológica, a seguridade social organiza-se como um sistema que engloba princípios, valores e objetivos políticos, econômicos e sociais que estão atrelados à organização de direitos, prestaçóes, financiamentos e gestão de proteção social, gerido, organizado pelo Estado, direta ou indiretamente, objetivando a cobertura de riscos ou contingências sociais que possam atingir os indivíduos.

Hodiernamente, é tarefa árdua definir com precisão o que é a seguridade social ${ }^{8}$. Além disso, não é possível se chegar a numa definição única que sirva para todos os ordenamentos jurídicos, pois são distintos os princípios políticos e jurídicos e as condiçóes econômicas e sociais que determinam a eleição dentre os vários sistemas de seguridade. Segundo Venturi (1954, p. 273).

o caráter fundamental da Seguridade Social é a sua original questão ética, o princípio da obrigação universal de garantir a todo o ser humano a tutela contra as consequências danosas que derivam dos eventos da vida individual, familiar e coletiva.

Dupeyroux (1969, p.80) por seu turno, adota uma concepção comutativa, afirmando que:

a seguridade social aparece como o sistema de garantias de rendas logradas pelo exercício de determinada atividade profissional, existindo os riscos perfeitamente catalogados que se cobrem tradicionalmente. Em troca do trabalho que é realizado, o trabalhador adquire o direito de receber determinadas prestações.

8 Quanto à denominação "seguridade social", ensina Celso Barroso Leite: "A expressão parece ter surgido nos Estados Unidos, com o 'Social Security Act' (Lei da Seguridade Social), de 1935; repetida logo após na lei neozelandesa sobre a mesma matéria, de 1938, ela firmou-se e conquistou aceitação internacional. Em seguida vieram sécuritésociale na França, 'sicurezzasociale' na Itália, 'seguridad social' na Espanha e América espanhola, 'seguridade social' no Brasil (porém não em Portugal, onde o que se diz é 'segurança social')". Conceito de seguridade social. BALERA, Wagner (Coordenador). Curso de direito previdenciário, em homenagem a Moacyr Velloso Cardoso de Oliveira. 5. ed. Sáo Paulo: LTR, 2002, p. 16. 
A seguridade social pode ser definida, a partir de duas concepçóes: a comutativa ou contributiva, que se baseia no exercício de atividade profissional e na contribuição de cada indivíduo e a distributiva, baseada no atendimento do indivíduo, a partir das suas necessidades vitais, independente de contribuição, levando em conta a existência de uma solidariedade entre os membros da mesma coletividade. ${ }^{9}$

O novo sistema de seguridade social - idealizado por William Beveridge na conceituada obra "O Plano Beveridge" (1943,p. 23-24) que defende a proteção "do berço ao túmulo", foi baseado em três princípios essenciais: o da universalidade, da unidade e o da integridade. Sendo assim, a seguridade social deve atingir a totalidade dos indivíduos, cobrindo o maior número possível de riscos e de forma integral que possibilite o desenvolvimento da personalidade de cada ser humano, como membro da sociedade. Estes aspectos constituem a estrutura de uma organização simples, coerente e completa de defesa contra a miséria. Propóe-se manter todos os membros da coletividade acima do nível considerado como mínimo, em todas aquelas eventualidades que podem afetar a garantia ou a adaptação das rendas ao grupo familiar.

A seguridade social foi introduzida no ordenamento jurídico pátrio vigente por meio da Constituição Federal de 1988 disciplinada no artigo 193, do Capítulo II, do Título VII (Da Ordem Social), que comanda: "A ordem social tem como base o primado do trabalho e como objetivo o bem-estar e a justiça sociais." Este artigo é norteador de todo sistema protetivo social, que está intimamente ligado ao artigo $1^{\circ}$, inciso IV, da Carta Fundamental, cujo dispositivo enuncia como fundamento da República Federativa do Brasil "os valores sociais do trabalho" que são, segundo o prof. Wagner Balera (2010, p.26), a "chave interpretativa para toda seguridade social".

O artigo 194, caput, da vigente Constituição Federal, ao tratar, especificamente, da seguridade social, conceitua dispóe que:

A seguridade social compreende um conjunto integrado de açóes de iniciativa dos Poderes Públicos e da sociedade, destinadas a assegurar os direitos relativos à saúde, à previdência e à assistência social.O legislador constitucional previu, também, no parágrafo único, do art. 194, os princípios norteadores do sistema de seguridade social, quais sejam: universalidade da cobertura e do atendimento; uniformidade e equivalência dos benefícios e serviços às populaçóes urbanas e rurais; seletividade e distributividade na prestaçáo dos benefícios e serviços; irredutibilidade do valor dos benefícios; equidade na forma de participaçáo no custeio; diversidade da base de financiamento; caráter democrático e descentralizado da administração, mediante gestão quadripartite, com participação dos trabalhadores, dos empregadores, dos aposentados e do Governo nos órgãos colegiados.

9 Na concepção comutativa as pessoas só podem utilizar o sistema de seguridade social se estiverem contribuindo; já para a concepção distributiva os indivíduos têm o direito de utilizar o sistema de seguridade social por possuírem necessidades vitais. 
A partir da leitura deste artigo pode-se afirmar que a seguridade social é um conjunto integrado de açóes que náo deve ser considerado isoladamente, pertencendo a um tronco comum as áreas da saúde, da previdência e da assistência social. Estas três áreas formam um conjunto, que por expressa disposição constitucional, deve ser integrado, sendo tais ações regidas pelos mesmos princípios inclusos no artigo 194, parágrafo único, da Carta Magna. O artigo 196 da Constituição Federal dispóe que "a saúde é direito de todos e dever do Estado". Neste sentido, todos devem gozar de boa saúde e ter acesso igualitário à assistência médica e hospitalar, se necessitar, independente de contribuição e filiação prévia. O sistema da saúde é regido pelos princípios da universalidade e da igualdade de acesso às açóes e serviços. Todos os indivíduos, independente de contribuiçáo ou filiação prévia, têm direito à saúde.

O artigo 201 da Constituição Federal dispóe que "a previdência social será organizada sob a forma de regime geral, de caráter contributivo e de filiação obrigatória”. Por conseguinte, qualquer pessoa poderá ter acesso às prestações previdenciárias, desde que se filie e contribua, por meio de seu salário, com exceção dos dependentes. Percebe-se que a previdência social possui duas características essenciais e distintas, quais sejam, a contributividade e a filiação prévia obrigatória. Também o art. 202, a partir da Emenda Constitucional n. 20/98, passou a regulamentar a previdência complementar, e por fim o artigo 203 e 204 da Constituição Federal tratam da assistência social. Dessa forma, o sistema de Seguridade Social deve atuar como um organismo que identifique e satisfaça as necessidades dos seres humanos devendo, juridicamente, realizar justiça social protegendo não só os trabalhadores, bem como a todos os indivíduos necessitados.

\section{Os Direitos Previdenciários nos Acordos e Convenções Coletivas}

A concretização e a formalização de instrumentos convencionais, convenção ou acordo coletivo do trabalho, reproduzem o resultado da negociaçáo coletiva, fruto do consenso entre as partes, mediante concessóes recíprocas, sempre fundadas na autonomia privada coletiva.

Vale destacar, ainda, que a seguridade social é definida na Constituição Federal, no artigo 194, caput, como um "conjunto integrado de açóes de iniciativa dos poderes públicos e da sociedade, destinadas a assegurar os direitos relativos à saúde, à previdência $e$ à assistência social". É, portanto, um sistema de proteção social que abrange os três programas sociais de maior relevância: a previdência social, a assistência social e a saúde. Ademais, a previdência social se preocupa, exclusivamente, com os trabalhadores e com os seus dependentes econômicos. É, ainda, desta espécie do gênero seguridade, a técnica de proteção social destinada a afastar necessidades sociais decorrentes de contingências 
sociais ${ }^{10}$ que reduzem ou eliminam a capacidade de autosustento dos trabalhadores e/ ou de seus dependentes.

Por último, é importante salientar, que em pesquisa feita por mim (FERRARO, Suzani Andrade) ${ }^{11}$ na investigação cientifica da minha tese de doutorada defendida pela PUC-SP, em 25.03.2015, ficou demonstrado, que atualmente os direitos previdenciários são recorrentes nas negociaçóes coletivas e que resultam cada vez mais em um número maior de cláusulas protetivas aos trabalhadores nas convençôes e nos acordos coletivos de trabalho. Ora, se as convenções e os acordos coletivos são fontes formais, de produção autônoma, instrumentos resultantes das negociaçóes coletivas do trabalho, entendo que as convençôes e os acordos coletivos do trabalho também são, incontestavelmente, fontes de direito previdenciário.

\subsection{A Força Cogente das Normas Previdenciárias nas Convenções e nos Acor- dos Coletivos e a Aplicação do Princípio da Ultratividade e o Princípio da Vedação ao Retrocesso Social}

Como foi visto anteriormente, a ultratividade da norma coletiva sempre foi motivo de muitas divergências entre a doutrina e as decisóes judiciais, afinal, grande parte dos doutrinadores brasileiros respeitava a norma coletiva dentro de seu prazo de validade, expirado o prazo, ela seria excluída, automaticamente, dos contratos de trabalho individuais. Todavia, segundo a teoria da ultratividade, a norma coletiva teria sua eficácia estendida mesmo depois de expirado o prazo de vigência da norma, quando não houver outra para substituí-la.

Com a alteração da súmula 277, o TST respaldou a ultratividade, e pacificou a ideia de que na convenção e/ou negociação coletiva, a norma anterior estenderá sua eficácia até ser substituída por outra, portanto, as cláusulas normativas passam a integrar os contratos individuais de trabalho.

Com o novo entendimento do Tribunal Superior do Trabalho, aumenta, consideravelmente, o risco das empresas que desejarem suprimir ou modificar direitos assegurados em negociaçóes coletivas anteriores, a não ser que haja nova convenção e/ou negociação coletiva. O aconselhável, caso as empresas pretendam negociar algum benefício em detrimento ao anterior, é que sejam estabelecidas negociaçóes com os sindicatos, antecipadamente, ao termo final da norma coletiva vigente.

10 Contingência social são fatos e/ou acontecimentos que, uma vez ocorridos, tem a força de colocar uma pessoa e/ou seus dependentes em estado de necessidade, como por exemplos invalidez (incapacidade), óbito, idade avançada, desemprego, maternidade, dentre outras prevista no art. 201 da Constituiçáo Federal Brasileira.

11 Os Acordos e Convençôes Coletivas de Trabalho como fonte de direito Previdenciário. Programa de doutorado em direito. (WWW.pucsp.br). 
Outro ponto a ser observado é a ausência de suporte jurídico desta modificação, tendo em vista que a ordem legal expressa determina a eficácia temporária dos acordos e convençôes coletivas, consoante o art. 614, $\$ 3^{\circ}$, da CLT -Consolidação das leis do Trabalho, sendo inegável que a ultratividade geral e indeterminada só poderia ser admitida mediante criação de lei específica, que assim dispusesse expressamente, o que não ocorreu, deixando-a “pendente” de eficácia. É necessário, no entanto, analisar se a ultratividade será benéfica aos empregados, como um avanço na proteção ao trabalho, como valor social, ou uma forma de congelar as conquistas sociais ali alcançadas, assim como avaliar se esta não será uma forma de acentuar ainda mais o desequilíbrio entre empregado e empregador, haja vista que a manutenção das cláusulas coletivas como "fixas", enquanto não houver uma nova, paralisa os direitos do trabalhador, por tempo indeterminado, o que seria ótimo para aqueles empregadores que entendem que "o que hoje foi negociado só foi aceito porque suportável". Por tal razão, entendo que é necessário ratificar que ultratividade também deve significar que as condiçóes mais favoráveis estabelecidas por Convenção ou Acordo Coletivo devem incorporar-se ao patrimônio jurídico do trabalhador e que não podem mais ser suprimidas.

Em verdade, ressalto que a não incorporação dessas normas mais benéficas ao patrimônio jurídico do trabalhador vai significar um retrocesso social, pois a proibição do retrocesso social confere aos direitos fundamentais, em especial, aos sociais, estabilidade nas conquistas dispostas na Carta Magna, assegurando aos trabalhadores que se um direito for alterado, esta alteração deverá passar por um longo processo de análise para que venha beneficiar seus destinatários.

Nesse sentido, entendo, também, que as garantias previdenciárias decorrentes de negociações coletivas têm força cogente não só durante o período de vigência da convenção ou acordo coletivo, mas por prazo indeterminado devendo ser incorporado ao contrato de trabalho do empregado, uma vez que essas garantias se incorporaram ao patrimônio jurídico do trabalhador.

Em verdade, como explica Wagner Balera (2010, p. 189), a Constituiçáo Federal, que em seu art. $3^{\circ}$, insculpe como fundamento a Ordem social cuja base é o primado do trabalho e o objetivo a atingir é o bem-estar e a justiça social, não cogita regressão das conquistas sociais já elevadas à dignidade constitucional. Ademais, acrescenta que o sistema jurídico só pode ser compreendido como um todo. Sendo assim, as normas jurídicas de hierarquia inferior devem guardar estrita harmonia com as normas hierarquicamente superior e nenhuma regra inferior poderá "furtar-se de implantação da diretriz de justiça estatuída na Lei Magna.”.

\section{Conclusões}

O poder é um elementoessencial ao conceito de fonte de direito. Este se diversifica em modalidades da forma do poder de decidir na experiência social. A fonte de direito 
implica no conjunto de pressupostos de validade que deve ser obedecido para que a produção de prescrições normativas seja considerada obrigatória e, assim, se projete na vida social e conduza a momentos diversos das atividades da sociedade civil e do Estado. A Constituição é a fonte máxima e suprema do direito constitucional nos países em que não pode ser modificada por lei ordinária, mas somente por processos especiais estabelecidos constitucionalmente. Consideram-se fontes constitucionais do direito previdenciário as fontes filosóficas que se transformam em direito positivo. No direito brasileiro, pela definição do artigo 193 da Constituição, há a seguinte expressão: "a ordem social tem como base o primado do trabalho e como objetivo o bem-estar e a justiça social”. A incumbência desse conjunto de princípios e normas é a de conduzir a sociedade ao estágio de bem-estar e justiça sociais sob o primado do trabalho.

São duas as finalidades da negociação coletiva: 1) fixar condiçôes individuais de trabalho e 2) estabelecer as condiçóes para o relacionamento entre aqueles que se engajam nas relaçóes coletivas de trabalho. Neste sentido, na Convenção n. 154 da Organização Internacional do Trabalho, a expressão "negociação coletiva" compreende todas as negociaçóes que têm lugar entre um empregador, um grupo de empregadores, uma organização ou várias organizaçóes de empregadores, de um lado, e uma organização ou várias organizaçóes de trabalhadores, de outro lado, com o fim de: a) fixar as condiçóes de trabalho e emprego; b) regular as relações entre empregadores ou trabalhadores; c) regular as relações entre empregadores ou suas organizações e uma organização ou várias organizações de trabalhadores, ou lograr todos esses fins concomitantemente.

A convenção e contrato coletivo têm, efetivamente, o mesmo sentido e significado efoi a instituição que, pela primeira vez, permitiu aos trabalhadores influir, real e positivamente, na determinação das condições de trabalho. A Organização Internacional do Trabalho, por meio da Recomendação no 91, de 1951, definiu o contrato coletivo como todo contrato escrito relativo às condiçóes de trabalho e emprego, celebrado entre um empregador, um grupo de empregadores ou uma ou várias organizaçóes de empregadores, por uma parte e, por outra, uma ou várias organizaçóes representativas de trabalhadores ou, na ausência de tais organizaçóes, representantes dos trabalhadores interessados, devidamente eleitos e autorizados por esses últimos, de acordo com a legislação nacional.

No Brasil, com a promulgação da Constituição de 1988, as convençóes e os acordos coletivos de trabalho passaram a ser expressamente garantidos no artigo 7o, inciso XXVI. $\mathrm{Na}$ acepção legal, convenção coletiva de trabalho, propriamente dita, é o instrumento celebrado entre os sindicatos representativos das categorias profissionais e econômicas, ou seja, é o diploma negocial de natureza intersindical. O acordo coletivo de trabalho é o meio negociado entre os sindicatos representativos das categorias profissionais e uma ou mais empresas da correspondente categoria economia, ou seja, de menor abrangência. 
A seguridade social pode ser definida, a partir de duas concepçóes: a comutativa ou contributiva, que se baseia no exercício de atividade profissional e na contribuição de cada indivíduo e a distributiva, baseada no atendimento do indivíduo, a partir das suas necessidades vitais, independente de contribuição, levando em conta a existência de uma solidariedade entre os membros da mesma coletividade, sendo um conjunto integrado de açóes que náo deve ser considerado isoladamente, pertencendo a um tronco comum as áreas da saúde, da previdência e da assistência social. Estas três áreas formam um conjunto, que por expressa disposição constitucional, deve ser integrado, tendo como objetivo principal a preservaçáo do primado do trabalho e o alcance do bem-estar e a justiça social, garantindo vida digna ao ser humano.

A aplicação do princípio da ultratividade da norma coletiva sempre foi motivo de muitas divergências entre a doutrina e as decisóes judiciais, afinal, grande parte dos doutrinadores respeitava a norma coletiva dentro de seu prazo de validade, expirado o prazo, ela seria excluída, automaticamente, dos contratos de trabalho individuais. Todavia, segundo a teoria da ultratividade, a norma coletiva teria sua eficácia estendida mesmo depois de expirado o prazo de vigência da norma, quando não houver outra para substituí-la. Com a alteração dessa súmula, o TST respaldou a ultratividade e pacificou a ideia de que na convenção e/ou negociação coletiva, a norma anterior estenderá sua eficácia até ser substituída por outra, portanto, as cláusulas normativas passam a integrar os contratos individuais de trabalho.

No entanto, levando em consideração o princípio da norma mais favorável entendo que é necessário ratificar que ultratividade também deve significar que as condiçóes mais favoráveis estabelecidas por Convenção ou Acordo Coletivo devem incorporar-se ao patrimônio jurídico do trabalhador e que não podem mais ser suprimidas, pois a não incorporação dessas normas mais benéficas ao patrimônio jurídico do trabalhador vai significar um retrocesso social e violação ao princípio da vedação do retrocesso social que confere aos direitos fundamentais, em especial, aos sociais, estabilidade nas conquistas dispostas na Carta Magna, assegurando aos trabalhadores que se um direito for alterado, esta alteração deverá passar por um longo processo de análise para que venha beneficiar seus destinatários.

Sendo assim, as garantias previdenciárias decorrentes de negociaçóes coletivas têm força cogente náo somente durante o período de vigência da convenção ou acordo coletivo, mas se incorporam ao patrimônio jurídico do trabalhador enquanto estiver em vigor a norma, ou seja, em período náo superior a 2 (dois) anos (artigo $614 \$$ 3o, da CLT). Ademais, a negociação coletiva, tem o poder de produzir, além de cláusulas contratuais, normas jurídicas.

\section{Referências}

AROUCA, José Carlos. Curso básico de direito sindical - 4a edição. São Paulo: LTr, 2014. 
BALERA, Wagner. Sistema de Seguridade Social. 5a Ed. São Paulo: LTr. 2009.

. Noçôes Preliminares de Direito Previdenciário. 2a Ed. Revista e ampliada. São Paulo: QuartierLatin. 2010.

. Competência Jurisdicional na Previdência Privada.São Paulo: Quartier Latin, 2007.

BANCO MUNIDIAL, Averting The Old Age Crisis - Policies to Protect the Old and Promote growth. New York: Banco Mundial, 1994.

BEVERIDGE, William. O Plano Beveridge, tradução Almir de Andrade, Rio de Janeiro: José Olympio, 1943.

BOBBIO, Norberto. Teoria do Ordenamento Jurídico. Tradução de Maria Celeste C. J. Santos. 10a Ed. Brasília: Editora Universidade de Brasília, 1997.

- Teoria da Norma Jurídica. Tradução Fernando Pavan Baptista e Ariane Bueno Sudatti. Ed. Edipro. Bauru: São Paulo. 2001.

BRITO FILHO, José Claudio Monteiro de. Direito sindical - 2a Edição. São Paulo: LTr, 2007.

CANOTILHO, J. J. Gomes. Direito constitucional e teoria da constituição. Coimbra: Almedina, 1998.

DELGADO, Mauricio Godinho. Princípios de direito individual e coletivo do trabalho. $4^{\mathrm{a}}$ Ed. São Paulo: LTr, 2013.

DUPEYROUX, Jean-Jacques. SecuriteSociale. Paris: UTET, 1969.

DWORKIN. Ronald, Taking rights seriously, Cambridge: Harvard University Press, 1997.

FAJARDO, Martins. Derecho de la seguridad social. 2 ed. Lima, Peru: 1985.

GOMES, Orlando; GOTTSCHALK, Élson. Curso de direito do trabalho.Atualizado por

GONÇALVES, Lilian. Ultratividade das cláusulas normativas. São Paulo: LTr, 2008.

HUECK, Alfred; NIPPERDEY, H. C. Compendio de Derecho del Trabajo. Revista de Derecho Privado, Madrid, 1963.

LOPES, Mônica Sette. A convenção coletiva e sua força vinculante. São Paulo: LTr. 1998.

MAGANO, Octavio Bueno. Procedimentos de autocomposição dos conflitos coletivos. Revista LTr, São Paulo: Ltr, vol. 54, n. 2, p.150-153, fev. 1990.

MORAES FILHO, Evaristo de. O problema do sindicato único no Brasil: seus fundamentos sociológicos, 2a Ed., São Paulo, Alfa - Omega, 1978.

NASCIMENTO, Amauri Mascaro. Compêndio de Direito Sindical. $7^{\text {a }}$ ed., São Paulo: LTr, 2000. 
. Teoria geral do direito do trabalho, 21 ed. Atual, São Paulo, LTr, 2003.

. Curso de Direito do Trabalho. 18 Ed. 2009.

REALE, Miguel. Fontes e modelos do direito. São Paulo: Saraiva, 1994.

. Filosofia do Direito. 12a Ed., São Paulo: Saraiva, 1987.

REIS, Daniela Muradas. O princípio da vedação do retrocesso no direito do trabalho. Sáo Paulo: LTr, 2010.

RODRIGUEZ, Américo Plá. Los princípios de derecho Del Trabajo. Montevidéu: MBA, 1975.

RUPRECHT, Alfredo J. Derecho colectivo del trabajo, Madri: Confederação Españolade Cajas de Ahorros, 1977.

SUSSEKIND, Arnaldo. Curso de Direito do Trabalho. Rio de Janeiro: Renovar, 2002.

SÜSSEKIND, Arnaldo; MARANHĀO, Délio; VIANNA, Segadas; TEIXEIRA Filho, João de Lima. Instituições de Direito do Trabalho. São Paulo:LTr., 2005, vol. I.

VENTURI, Augusto. I fundamentiscientificidellaSicurezzaSociale. Milão. UTET, 1954.

ZANGRANDO, Carlos. Princípios jurídicos do direito trabalho. 2a Ed. São Paulo: LTr, 2013. 